\title{
A COMPARISON OF OBSERVED AND CALCULATED AVALANCHE VELOCITIES
}

\author{
By Edward R. LaChapelle \\ (Geophysics Program and Department of Atmospheric Sciences, University of Washington, \\ Seattle, Washington 98195, U.S.A.) \\ and Theodore E. LANG \\ (Department of Civil Engineering and Engineering Mechanics, Montana State University, \\ Bozeman, Montana 597 I 7 , U.S.A.)
}

\begin{abstract}
Velocities have been derived from motion-picture film of two different avalanches falling in known terrain. These data are used to calculate avalanche behavior according to the method of Voellmy and the method of Lang and others. Results suggest that Voellmy's coefficient of turbulent flow may be related to snow density and temperature as much as it is to terrain roughness. For avalanche flow modelled as a transient, viscous process, specification of friction coefficient and kinetic viscosity over a limited range of values successfully predicts a wide range of avalanche behavior.

RÉsumé. Une comparaison entre les vitesses observées et calculées pour les avalanches. A partir d'un film de photo de leur mouvement, on a estimé les vitesses de deux avalanches différentes tombant sur un terrain connu. On utilise ces données pour calculer le comportement de l'avalanche selon la méthode de Voellmy et la méthode de Lang et alt. Les résultats montrent que le coefficient d'écoulement turbulent de Voellmy peut être relié à la température et à la densité de la neige autant qu'à la rugosité du terrain. Pour un écoulement d'avalanche modélisé comme non-permanent, la spécification de processus visqueux par un coefficient de friction et une viscosité cinétique dans une gamme limitée de valeurs peut rendre compte avec succès d'une grande variété de comportements d'avalanches.

Zusammenfassung. Ein Vergleich zwischen beobachteten und berechneten Lawinengeschwindigkeiten. Aus Filmaufnahmen zweier verschiedener Lawinenabgänge in bekanntem Gelände wurden Geschwindigkeiten hergeleitet. Diese Daten werden zur Berechnung des Lawinenverhaltens nach der Methode von Voellmy sowie nach der von Lang u.a. benutzt. Die Ergebnisse deuten darauf hin, dass Voellmy's Koeffizient des turbulenten Flusses ebenso stark von der Schneedichte und -temperatur wie von der Geländerauhigkeit abhängen kann. Betrachtet man den Lawinenfluss als einen vorübergehenden, viskosen Vorgang, so lässt sich mit der Festlegung des Reibungs-Koeffizienten und der kinetischen Viskosität auf einen begrenzten Wertvorrat ein grosser Bereich des Lawinenverhaltens erfolgreich vorhersagen.
\end{abstract}

\section{INTRODUCTION}

We have recovered avalanche velocities and flow characteristics from motion-picture films taken of two avalanches falling in different terrain, each with known vertical and transverse profiles. One of these is the Brooklyn B avalanche, designated No. o 6 by Miller and others (1976, p. 55), in the San Juan Mountains of south-west Colorado. The other is the Slushman avalanche in the Bridger Range of southern Montana. Accurate vertical profiles of the two avalanche paths are shown in Figure I from which slope measurements may be estimated. The Slushman profile continues at approximately $16^{\circ}$ slope for an extended distance beyond the last station noted in Figure I. The Brooklyn B avalanche fell as a soft slab in mid-winter from a release zone altitude of $3300 \mathrm{~m}$, involving cold, low-density snow. The Slushman avalanche fell as a hard slab in late winter from a release-zone altitude of $2660 \mathrm{~m}$, involving warmer, denser snow which reached a wet condition in the run-out zone. The crown fracture height varied between $1.0 \mathrm{~m}$ and $1.5 \mathrm{~m}$ over a width of approximately $70 \mathrm{~m}$. The Stauchwall was approximately $50 \mathrm{~m}$.down the slope. The avalanche was triggered by cornice fall, which added, by our estimate, 20 to $30 \%$ to the released mass. Residual cornice hazard precluded measurements in the starting zone after the avalanche. The Brooklyn B avalanche fell on a nearly open slope covered with scattered alpine firs, seven of which served as measured reference points for estimating intermediate leading-edge positions of the flowing snow recorded on the motion-picture film. The release slab of the Brooklyn B 


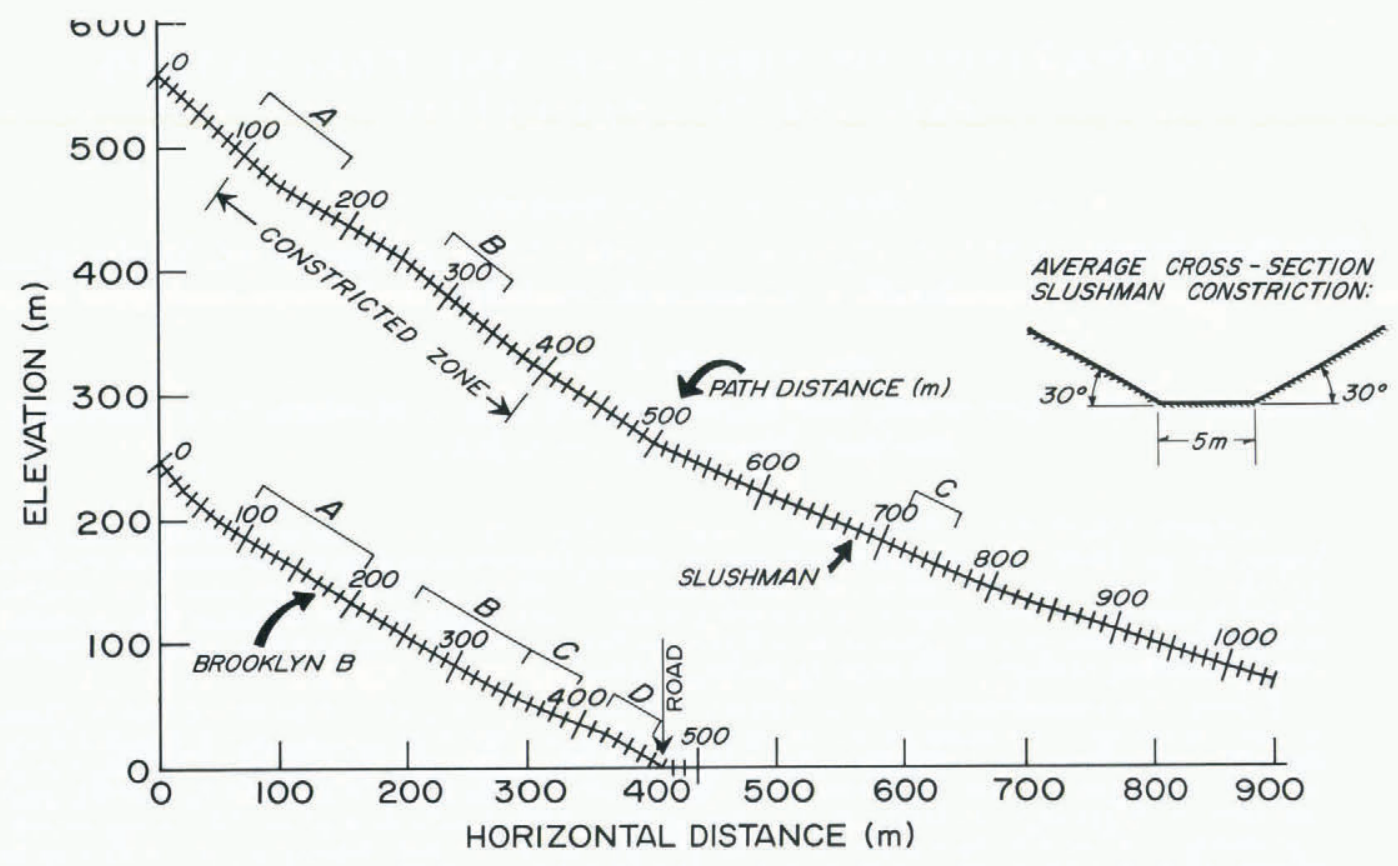

Fig. I. Center-line profile of Brooklyn B and Slushman avalanche paths. The starting zone starts at the top cell of each profile.

had a thickness between 0.5 and $1.0 \mathrm{~m}$, and an estimated square surface area of $30 \mathrm{~m}$ dimension. The Slushman avalanche released on an open slope, flowed $400 \mathrm{~m}$ through a constricted region where six trees and rock outcrops were used as reference points, then flowed into an open run-out zone where ten pre-planted flags served as references. Computed mean leadingedge velocities over path segments between reference points are shown by the I's in Figure 2. The height of each I represents the limits obtained from several readings of the film by different interpreters. The Brooklyn B avalanche stopped at the road indicated in Figure I, while the Slushman avalanche crept at low speed for a considerable (not measured) distance beyond station rooo noted in Figure I. Parallax problems were encountered in reduction of both data sets, leading to an error which is difficult to estimate.

\section{Calculation by the method of Voellmy}

Voellmy (1955) introduced a widely used method of calculating avalanche behavior based on the assumption that flowing avalanche snow essentially was similar to water flow in open channels. His basic equation for flow velocity takes the following form:

$$
V=\left[\xi h^{\prime}(\sin \psi-\mu \cos \psi)\right]^{\frac{1}{2}},
$$

where $V$ is the avalanche velocity, $h^{\prime}$ the flow height, $\psi$ the slope angle, $\mu$ the coefficient of sliding friction, and $\xi$ the coefficient of turbulent friction.

Various authors have proposed different values of $\xi$ typical of different snow and slope conditions; the most widely used are those proposed by Schaerer ([1975]) on the basis of many avalanche motion observations. Schaerer also was able to show that $\mu$ could take the value 5/V over the range io $<V<50 \mathrm{~m} \mathrm{~s}^{-1}$, a convention adopted except for the Slushman outrun, where low velocities give unreasonably large values for $\mu$, arbitrarily taken as 0.3 for this location. Avalanche flow height $h^{\prime}$ is available for the present cases by direct inspection of the 


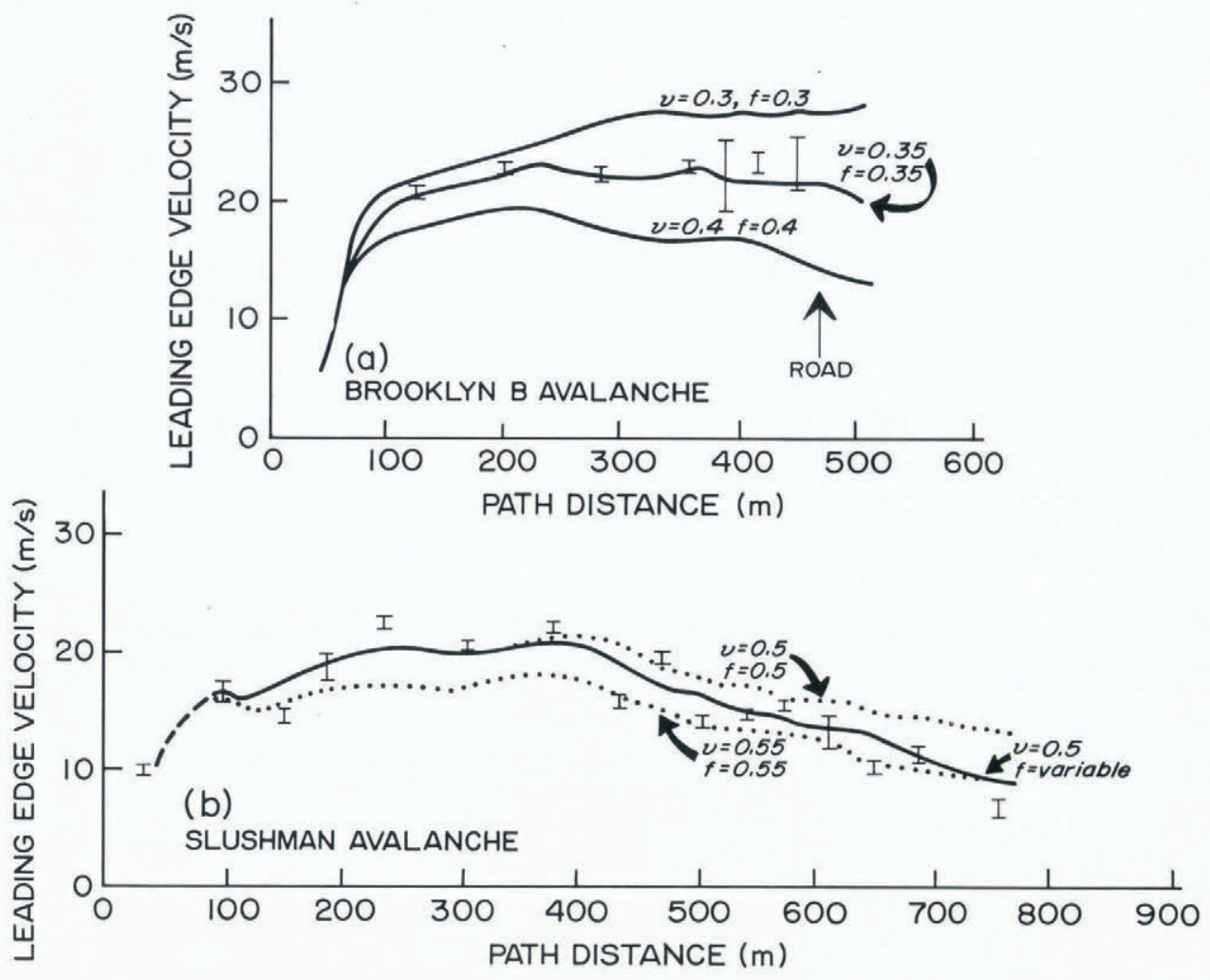

Fig. 2. Measured and computed avalanche velocity profiles.

filmed flow height in comparison to the size of known references, except for the Slushman release zone, where Voellmy's convention is followed of taking $h^{\prime}=h$, the measured thickness of the released slab. In each case $h^{\prime}$ was taken as the height of the visible avalanche front, clearly mixed motion dominated by flowing snow for Brooklyn B (Fig. 3) and the same for the upper Slushman.

The Voellmy calculations were made for avalanche-path sections designated A through C and A through D for the Slushman and Brooklyn B avalanches, respectively (Fig. I). Distances and slope angles were obtained by direct measurement in the field. All the Brooklyn B sections were treated as open slopes, as were the upper and lower Slushman sections. The middle Slushman section (B) was treated as confined flow with the hydraulic radius $R$ substituted for $h^{\prime}$ in Voellmy's equation. The profitable exercise here is not to calculate avalanche velocities, which require assumptions about $\xi$, but rather to take the known velocities and solve for $\xi$. The results are summarized in Table I and discussed below in the Conclusions section.

Formally, the Voellmy method is severely limited because it is invalid for movements with local accelerations, applies to internal snow flow and not the avalanche front, does not describe motion of the airborne dust cloud, and requires that the equation of continuity be satisfied. Avalanche observations in the real world, including ours, seldom meet these criteria. The role of local accelerations in determining friction coefficients lies beyond the scope of this paper. We equate here the avalanche-front velocity with flow velocity, following the widely used practical convention in such papers as those of Voellmy and Schaerer cited 


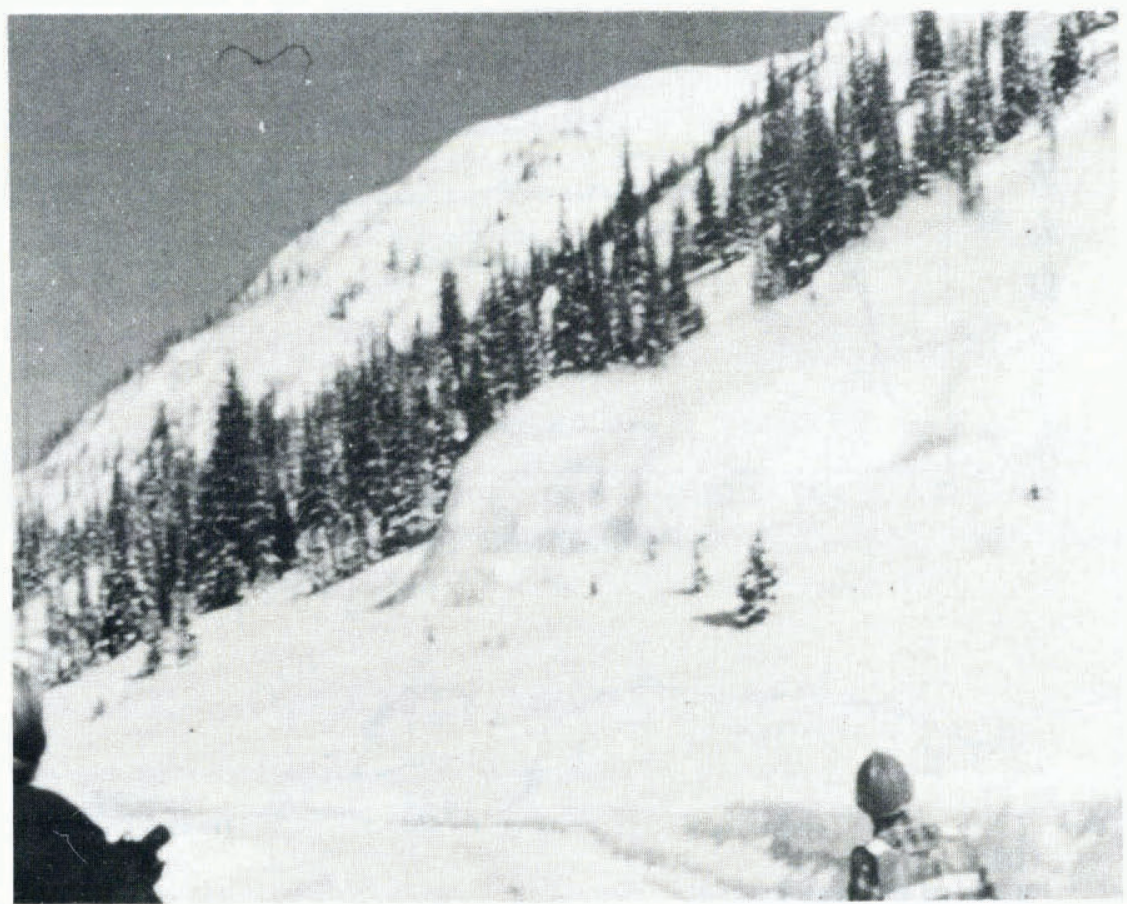

Fig. 3. Brooklyn B avalanche approaching road.

TABLE I. DATA From AVALANChes AND VALUE of $\xi$ Galculated From them BRooKLyn B (San Juan Mountains, Colorado)

$\begin{array}{cccccc}\text { Path section } & \begin{array}{c}V \\ \mathrm{~m} \mathrm{~s}^{-1}\end{array} & \begin{array}{c}h^{\prime} \\ \mathrm{m}\end{array} & \begin{array}{c}\psi \\ \mathrm{deg}\end{array} & \mu & \begin{array}{c}\xi \\ \mathrm{m} \mathrm{s}^{-2}\end{array} \\ \text { A } & 21.4 & 1.0 & 35 & 0.23 & \text { 1 200 } \\ \text { B } & 22.3 & 1.4 & 30 & 0.22 & \text { 1 } 160 \\ \text { C } & 23.4 & 1.6 & 28 & 0.21 & \text { I 200 } \\ \text { D } & 24.4 & 2.0 & 25 & 0.20 & \text { I 26o }\end{array}$

Slushman (Bridger Range, Montana)

$\begin{array}{crrrrrc}\text { Path section } & \begin{array}{c}V \\ \mathrm{~m} \mathrm{~s}^{-1}\end{array} & \begin{array}{c}h^{\prime} \\ \mathrm{m}\end{array} & \begin{array}{c}R \\ \mathrm{~m}\end{array} & \begin{array}{c}\psi \\ \mathrm{deg}\end{array} & \mu & \begin{array}{c}\xi \\ \mathrm{m} \mathrm{s}^{-2}\end{array} \\ \text { A } & 15.5 & \mathbf{1 . 2} & - & 38 & 0.32 & 550 \\ \text { B } & 20.5 & - & 1.5 & 36 & 0.25 & 725 \\ \text { C } & 6.5 & \mathbf{1 . 5} & - & 2 \mathrm{1} & 0.3^{*} & 360\end{array}$

* Assumed.

above. The two avalanches we describe have only a limited dust cloud and we take $h^{\prime}$ to be the observed front height. In both continuity obviously is not conserved owing to lateral flow and entrainment, a common feature of many avalanches. The obtained values of $\xi$ are useful for approximating avalanche behavior with these limits in mind. In the next section we utilize a calculation method with fewer constraints.

\section{Calculation using program AVALNCH}

The solid lines in Figure 2 are velocity profiles obtained from a computer code, designated AVALNCH, recently developed for predicting avalanche run-out (Lang and others, I979). The code is a finite-difference formulation of the two-dimensional Navier-Stokes equations 
for viscous, incompressible fluid flow. The two-step code predicts velocity and pressure initially using the non-linear Navier-Stokes equations, then uses a linear approximation to these equations to move material iteratively through the grid as the fluid advances. Boundary conditions are of the ordinary fluid-dynamics type except at the bottom surface where a slip condition is imposed, based upon a specified friction coefficient $f$. The other basic fluid parameter that must be specified is the kinematic viscosity, $\nu$. Geometric input to the code is the center-line profile of the avalanche path, which may be taken from topographic maps as shown in Figure I. For the Brooklyn B avalanche, which had a significant mixed-motion component and a low snow density $\rho$ (estimated $200-250 \mathrm{~kg} \mathrm{~m}^{-3}$ ), the relatively low values of $\nu=0.35 \mathrm{~m}^{2} \mathrm{~s}^{-1}$ and $f=0.35$ result in a reasonable fit to the observed avalanche flow. The Slushman avalanche (Fig. 4) is more complex, in that snow in the starting zone was dry

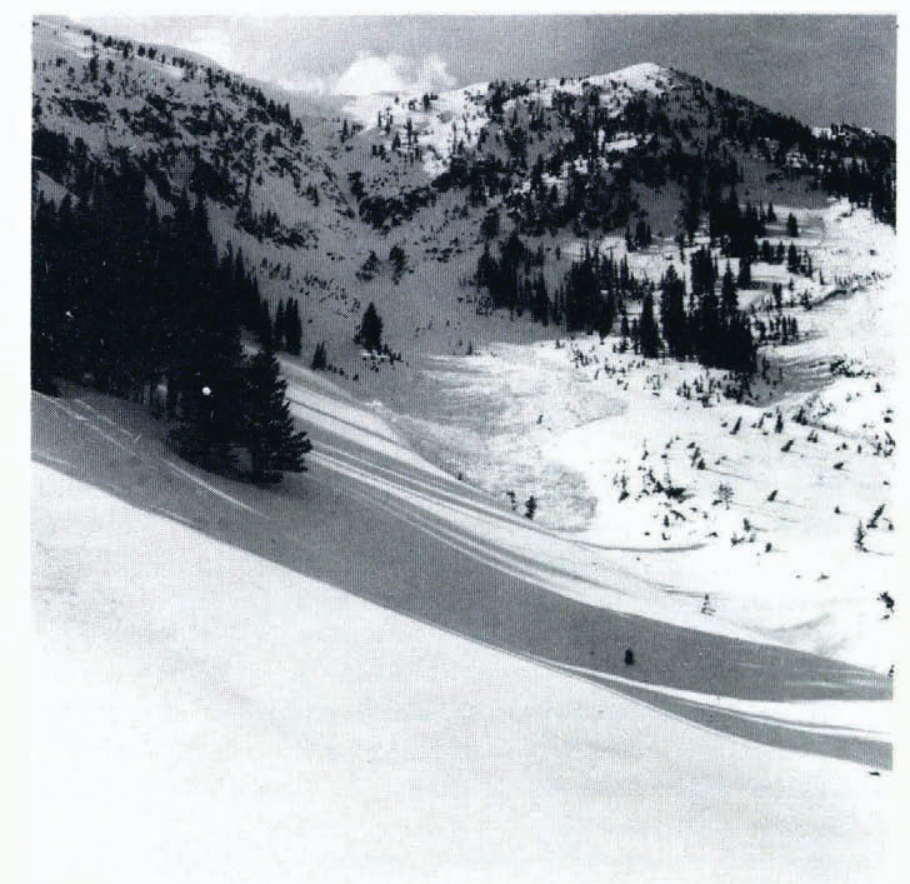

Fig. 4. Slushman avalanche in run-out zone. Photograph courtesy Dr R. Oakberg.

$\left(\rho=400 \mathrm{~kg} \mathrm{~m}^{-3}\right)$, whereas snow in the run-out zone had reached a melting state. Using equal and constant values of $v$ and $f$ over the entire path results in the dotted curves of Figure 2b. If $\nu=0.5 \mathrm{~m}^{2} \mathrm{~s}^{-1}$ over the entire path for the internal dissipation and $f=0.5$ over the initial $400 \mathrm{~m}$, then $f=0.55$ for the remainder of the path yields a velocity profile that fits the observed data (solid line in Fig. 2b).

\section{Conclusions}

The Voellmy equation applied to the low-density, dry Brooklyn B avalanche yields remarkably consistent values for the turbulent friction coefficient $\xi$ over varying slope angles and flow velocities, values close to the lower limit of $\mathrm{I} 200 \mathrm{~m} \mathrm{~s}^{-2}$ recommended by Schaerer (as cited by Leaf and Martinelli, I977) for flow over smooth, open snow slopes. The presence of scattered trees and irregular terrain apparently has no serious effect on avalanche flow for this kind of snow. The lower values of $\xi$ found for the Slushman avalanche are consistent with 
Schaerer's recommendations for average mountain slopes and gulleys, $400-750 \mathrm{~m} \mathrm{~s}^{-2}$, implying that these values are valid in such terrain for warmer, denser snow. The rather low value for the open Slushman release zone suggests that the hard, dense slab snow there exhibited different flow characteristics than did the dry, cold snow of the Brooklyn B avalanche. The even lower value of $\xi$ found for the Slushman run-out zone characterizes a shift to a much slower flow mode for wet snow at a location where more smooth, open terrain might be expected to induce a higher value of $\xi$.

In numerical modeling of avalanche flow as a transient, viscous process, by program AVALNCH, path geometry is separated from the dissipative mechanisms of internal viscosity and surface friction. Surface friction of $f=0.35$ and kinematic viscosity $v=0.35 \mathrm{~m}^{2} \mathrm{~s}^{-1}$ apply to modeling of the Brooklyn B dry, light-snow avalanche, and $f=0.5$ to 0.55 and $\nu=0.5 \mathrm{~m}^{2} \mathrm{~s}^{-1}$ apply to the Slushman wet-snow avalanche. Thus, the physical basis for choice of values of these parameters is associated with the characteristics of the snow mass within the avalanche, as well as the snow, or other material, constituting the stationary basal track. The results of program AVALNCH show rapid acceleration of the snow mass at the start of the avalanche, and leveling to more uniform flow velocities during the major portion of the run. This characteristic fits well with the observed and measured avalanche behavior of the two cases reported. Further refinement in $\nu$ and $f$ for different snow and terrain conditions is predicted upon additional field data, particularly of avalanches of higher overall speeds.

\section{AGKnowledgement}

Data collection for the Slushman avalanche was made possible through the support of Dr M. Martinelli, Jr of the Rocky Mountain Forest and Range Experiment Station, Fort Collins, Colorado, under cooperative agreement No. 16-778-CA, and field support by $\mathrm{Mr}$ Bruce Barker, Mountain Manager of Bridger Bowl Ski Area and Mr Duain Bowles, Dr Robert Brown, Mr Jimmie Dent, and Mr Clarence Serfoss, all at Montana State University.

The Brooklyn B data were collected as part of work for the Institute of Arctic and Alpine

Research, University of Colorado, under Bureau of Reclamation No. I4-o6-D-7I 55.

MS. received 29 March 1979 and in revised form 3 I May 1979

\section{REFERENCES}

Lang, T. E., and others. I979. Application of numerical transient fluid mechanics to snow avalanche flow. Part I. Development of computer program AVALNCH, by T. E. Lang, K. L. Dawson, and M. Martinelli, Jr. Journal of Glaciology, Vol. 22, No. 86, p. 107-15.

Leaf, C. F., and Martinelli, M., jr. 1977. Avalanche dynamics: engineering applications for land use planning. U.S. Dept. of Agriculture. Forest Service. Research Paper RM-1 83 .

Miller, L., and others. I 976 . Avalanche atlas San Juan County, Colorado, by L. Miller, B. R. Armstrong, and R. L. Armstrong. University of Colorado. Institute of Arctic and Alpine Research. Occasional Paper No. I 7.

Schaerer, P. A. [1 1975.] Friction coefficients and the speed of flowing avalanches. [Union Géodésique et Géophysique Internationale. Association Internationale des Sciences Hydrologiques. Commission des Neiges et Glaces.] Symposium. Mécanique de la neige. Actes du colloque de Grindelwald, avril 1974, p. 425-32. (IAHS-AISH Publication No. I I4.)

Voellmy, A. 1955. Über die Zerstörungskraft von Lawinen. Schweizerische Bauzeitung, Jahrg. 73, Ht. 12, p. I $59-62$; Ht. I 5 , p. 212-1 7; Ht. I 7, p. 246-49; Ht. 19, p. $280-85$. 